\title{
EFFECT OF NITROGEN FERTILISER ON GROWTH AND PRODUCTION OF APPLES IN THE CONDITIONS OF LATVIA
}

\author{
Valentīna Pole ${ }^{\#}$, Imants Missa, Edgars Rubauskis, Egils Kalva, and Sanita Kalva \\ Institute of Horticulture, Latvia University of Agriculture, Graudu iela 1, Ceriṇi, Krimūnu pag., Dobeles nov., LV-3701, LATVIA \\ Corresponding author, valentina.pole@llu.Iv
}

Communicated by Aldis Kārklinšs

\begin{abstract}
Nitrogen is a nutrient necessary for many functions of plants, e.g. shoot growth, fruit and flower bud set, and fruit size. In Latvia use of mineral fertilisers is limited by EU Directives and Regulations developed on the basis of the Guidelines of Integrated Production. The aim of the study was to investigate the effect of nitrogen $(N)$ fertiliser on apple growth and production in the conditions of Latvia. The study was performed during 2013 to 2015. In an apple trial, seven cultivars on rootstock B.396 were planted in 2009. There were two fertiliser treatments: without fertilising and N 6 $g \cdot \mathrm{m}^{-2}$. Significant effect of treatment was observed only in cultivar 'Ligol'. Tree crown in the $N$ treatment was over-dense, shoots too long, yet all cultivars had over-long shoots also in the unfertilised treatment. Effect of nitrogen in regard to amounts of acceptable and unacceptable shoots of the cultivars included in trial was negative. Nitrogen significantly increased the amount of unacceptable shoot types of cultivars 'Gita', 'Rubin' (Kazakhstan), and 'Ligol'. Additional nitrogen as fertiliser had no significant effect on growth and yield of cultivars 'Antei', 'White Transparent' and 'Konfetnoye.' The cumulative yield of 'Kovalenkovskoye' and 'Ligol' was positively affected by nitrogen fertiliser. The most pronounced biennial yielding was observed for cultivar 'Rubin'. Cultivar 'Ligol' had the most active and longer vegetation, especially in the nitrogen fertilisers treatment.
\end{abstract}

Key words: Malus, nutrients, orchard management.

\section{INTRODUCTION}

Nitrogen is one of the most important nutrients necessary for many functions of plants, e.g. shoot growth, fruit and flower bud set, and fruit size. If apple trees have insufficient uptake of nitrogen, shoot growth is weak, leaves become light green to yellowish-green, which has negative effect on photosynthetic intensity (Cmelik et al., 2006; Fallahi et al., 2010). Some growers prefer to apply nitrogen in excess to avoid problems related with insufficient availability of $\mathrm{N}$ to plants, especially in orchards (Weinbaum et al., 1992; Tagliavini et al., 1996). Excess $\mathrm{N}$ use is also promoted by prices of the fertilisers, which represents a small part of the total expenses of production. However, there are some consequences if $\mathrm{N}$ availability to plants is out of control - excessive growth, dense canopy, and decreased effectiveness of plant protection means, increase of work to manage created problems, etc.

Once nitrogen fertilisers are applied to agricultural systems, the fertilisers are absorbed directly by plants or converted into various other forms. Excess nitrogen can be lost in ionic or gaseous form through leaching, volatilisation, and denitrification (Tamme et al., 2009). If nitrates are not absorbed by plant roots, generally they are carried away by runoff or leach into the soil along with water (Teravist $e t$ al., 2010; Sharifi et al., 2011). There is a close relationship between the excessive application of nitrogen fertilisers and environmental problems such as eutrophication, the greenhouse effect, and acid rain (Gastal and Lemaire 2002; Wang et al., 2002). The $\mathrm{NO}_{3}{ }^{-}$form of nitrogen is most suitable for direct uptake by plant roots. It is also the form of nitrogen with the greatest potential for leaching to groundwater.

When soil $\mathrm{pH}$ is high, $\mathrm{NH}_{4}{ }^{+}$can be transformed to gaseous ammonia $\left(\mathrm{NH}_{3}\right)$ and volatilised. When soils are excessively wet, $\mathrm{NO}_{3}{ }^{-}$can be converted to $\mathrm{N}_{2}$ gas by soil microorganisms. The released molecular oxygen can be used for respiration of some microorganisms in wet soil conditions, when $\mathrm{O}_{2}$ is insufficient in soil. High nitrate concentration in groundwater and crops can have negative effect on human health as well (Chen et al., 2012).

Therefore, rational fertiliser application is an important issue in sustainable agriculture (Chen et al., 2002). While sustainable fruit growing is developing in Latvia, use of 
mineral fertilisers, especially nitrogen-containing mineral fertilisers, is limited by the EU Nitrates Directive and the regulations of the Republic of Latvia.

Problems associated with fertilising are closely related to other agro-technical operations. In recent years, because of periodical moisture deficit in soil, fruit growers are looking for soil moisture regulation technologies: irrigation and fertigation systems. In Latvia nowadays apple-trees in commercial orchards are planted mostly on dwarf or medium vigour vegetative propagated rootstocks, which have a root system morphologically different (more compact and shallow) from that of seedling rootstocks (Surikova et al, 2008; Nielsen et al., 2015). Therefore, the trees have also different demand for the growing conditions.

The aim of the study was to investigate the effect of nitrogen fertiliser on apple growth and production in the conditions of Latvia.

\section{MATERIALS AND METHODS}

During 2013-2015, the investigation was performed at the Institute of Horticulture (Dobele) in a trial planted in 2009 using cultivars 'Konfetnoye', 'Kovalenkovskoye', 'White Transparent', 'Gita', 'Antei', 'Ligol' and 'Rubin' (Kazakhstan) on rootstock B.396. The planting distance of the trees was $1.5 \times 4 \mathrm{~m}$ (1666 trees per 1 ha). Grasses Lolium perenne L. and Poa pratensis L. were sown in proportion $1: 3$ in the separating rows (3 $\mathrm{m}$ wide). During following vegetation periods, "weeds" such as white clover (Trifolium repens) and dandelion (Taraxacum officinale) spread in the grass lawn. During the growing seasons, the grass was regularly mown and the tree strips were maintained free of the grasses using herbicides such as glifosate and or basta. The canopies of trees were trained as slender spindles. Drip irrigation was used.

In the period of investigation the average air temperature was $7.4{ }^{\circ} \mathrm{C}(2013)-7.9{ }^{\circ} \mathrm{C}(2014)$, precipitations: $387 \mathrm{~mm}$ (2015) - $611 \mathrm{~mm}$ (2013), in the period of vegetation: 226 $\mathrm{mm}(2015)-502 \mathrm{~mm}$ (2013), and sum of positive temperature: $2507{ }^{\circ} \mathrm{C}(2015)-2916{ }^{\circ} \mathrm{C}(2013)$.
Soil of the experimental plot was Haplic Luvisol (Hypereutric), sandy loam, organic matter content $-21 \mathrm{~g} \cdot \mathrm{kg}^{-1}$ (Tyurin method), pH 6.8 (in $1 \mathrm{M} \mathrm{KCl}$ ). Plant available $\mathrm{P}_{2} \mathrm{O}_{5}$ was $214 \mathrm{mg} \cdot \mathrm{kg}^{-1}$ and $\mathrm{K}_{2} \mathrm{O} 113 \mathrm{mg} \cdot \mathrm{kg}^{-1}$ (DL method).

In the investigation of nitrogen use practice, two treatments were compared: control (without fertilisers) and fertilisation treatment ( $6 \mathrm{~g}$ of $\mathrm{N}$ per $1 \mathrm{~m}^{2}$ only) along a $1-\mathrm{m}$ wide tree row.

At the end of the vegetation period, shoots development was estimated. Shoots were counted in two length classes: less than and over $40 \mathrm{~cm}$. The yield $(\mathrm{kg})$ per tree, fruit weight $(\mathrm{g})$ and index of biennial bearing (index of alternance) was calculated as difference of two yields divided by sum of two yields, in two following years (Skrivele et al, 2000) (where 0 - annual yielding trees, 1 — strictly biennial yielding). The nitrogen content of leaves and fruits was analysed by Kjeldahl method. The trunk circumference was measured at $20 \mathrm{~cm}$ above grafting union and trunk crosssectional area (TCSA) calculated. Also leaf colour and tree defoliation were estimated on a 9-point scale, where 0 leaves are green and on the tree, 9 - leaves are fallen.

The statistical data analysis was performed by ANOVA and coefficients of correlations were calculated.

\section{RESULTS}

Additional nitrogen application did not raise significant amount of shoots less than $40 \mathrm{~cm}$ in length (Table 1). However, there was significant difference between cultivars and some interactions were observed. In 2013, cultivar 'Gita' had more short shoots in the control treatment, but in both next seasons this cultivar had more short shoots in the nitrogen treatment. 'Ligol' developed more short shoots in the nitrogen treatment; however, the difference between treatments was significant only in 2013 and 2015. During 2013 and 2014, 'Konfetnoye' developed more shoots $40 \mathrm{~cm}$ length in the nitrogen treatment. There were no significant difference in shoot development between treatments of cultivars 'Antei', 'Kovalenkovskoye', and 'White Transparent'. In general, there was relatively less short shoot devel-

Table 1 AMOUNT OF SHORT SHOOTS (SHOOT LENGTH 40 CM) IN RELATION TO CULTIVAR AND FERTILISER TREATMENT

\begin{tabular}{|c|c|c|c|c|c|c|}
\hline \multirow[t]{2}{*}{ Cultivars } & \multicolumn{2}{|c|}{2013} & \multicolumn{2}{|c|}{2014} & \multicolumn{2}{|c|}{2015} \\
\hline & Control & Fertilised & Control & Fertilised & Control & Fertilised \\
\hline White Transparent & $14^{\mathrm{b}}$ & $14^{\mathrm{b}}$ & $16^{\mathrm{a}}$ & $15^{\mathrm{a}}$ & $19^{\mathrm{a}}$ & $20^{\mathrm{a}}$ \\
\hline Konfetnoye & $9^{\mathrm{a}}$ & $12^{\mathrm{b}}$ & $16^{\mathrm{a}}$ & $20^{\mathrm{b}}$ & $19^{\mathrm{a}}$ & $19^{\mathrm{a}}$ \\
\hline Kovalenkovskoye & $18^{\mathrm{c}}$ & $17^{\mathrm{c}}$ & $19^{\mathrm{b}}$ & $20^{\mathrm{b}}$ & $20^{\mathrm{a}}$ & $20^{\mathrm{a}}$ \\
\hline Antei & $17^{\mathrm{c}}$ & $19^{c}$ & $17^{\mathrm{a}}$ & $17^{\mathrm{a}}$ & $17^{\mathrm{a}}$ & $19^{\mathrm{a}}$ \\
\hline Gita & $19^{c}$ & $15^{\mathrm{b}}$ & $18^{\mathrm{a}}$ & $22^{\mathrm{b}}$ & $16^{\mathrm{a}}$ & $22^{\mathrm{b}}$ \\
\hline Ligol & $18^{\mathrm{c}}$ & $26^{\mathrm{d}}$ & $16^{\mathrm{a}}$ & $18^{\mathrm{a}}$ & $17^{\mathrm{a}}$ & $21^{\mathrm{b}}$ \\
\hline Average & 15 & 16 & 17 & 18 & 17 & 19 \\
\hline
\end{tabular}

a, b, c and d-marked statistically significant ( $p<0.05$, Tukey) different groups of cultivar data within treatments (columns). 
opment by cultivar 'Rubin', in 2013 also by 'White Transparent' and 'Konfetnoye'. These last mentioned cultivars on dwarf rootstock developed small amount of both types of shoots and formed a relatively thin canopy.

Nitrogen fertilisers had a positive effect on the development of long shoots $(>40 \mathrm{~cm})$ (Table 2$)$, with a significant $(p<$ 0.05) difference in 2015. There was a significant difference between cultivars. 'Antei' and 'White Transparent' had smaller amounts of long shoots in the fertiliser treatment. The most pronounced effect of nitrogen fertilisers was observed for 'Ligol', and in some years for 'Konfetnoye', 'Rubin' and 'Gita'. There was no significant difference between cultivars in the control treatment (2013 and 2015) regarding development of long shoots.

Cumulative growth (TCSA) was calculated as increase of trunk cross-sectional area during the study period. Average increase of TCSA was significantly $(p<0.05)$ larger in the fertiliser treatment, particularly for 'Gita' and 'Ligol' (Table 3). Almost no difference between treatments was observed for 'Konfetnoye' and 'Kovalenkovskoye'. Positive correlation was found between increase of TCSA and amount of short shoots $(\mathrm{r}=0.74)$.
General effect of fertilisers on cumulative yield during study period was not observed (Table 3). However, there were some significant $(p<0.05)$ differences between cultivars and their interactions with treatments. Largest cumulative yield during study period was observed for 'Gita' and 'Ligol'. Significantly lower yield was obtained for 'White Transparent', 'Konfetnoye', 'Antei', and 'Rubin', and these cultivars had no significant difference between fertilisation treatments. However, cultivars with larger yields had positive reaction to nitrogen fertiliser treatment; yield of 'Ligol' and 'Kovalenkovskoye' increased by 8 and $21 \%$ respectively, reaching average per year of 21.8-24.2 $\mathrm{t} \cdot \mathrm{ha}^{-1}$ in the nitrogen treatment during fifth to seventh years after planting. 'Gita' had better yield in the control treatment $26.9 \mathrm{t} \cdot \mathrm{ha}^{-1}$ per year.

Index of biennial bearing was not affected by nitrogen fertiliser treatment. Significant differences between cultivars and trial factor interactions were observed. During the sixth and seventh vegetation seasons, 'White Transparent', 'Konfetnoye', 'Kovalenkovskoye', and 'Gita' had less pronounced biennial bearing (Table 4). 'Antei' and 'Ligol' showed biennial bearing, and tehre was a negative effect of nitrogen treatment on yield of 'Rubin'.

Table 2

AMOUNT OF LONG SHOOTS (SHOOT LENGTH $40 \mathrm{CM}$ ) IN RELATION TO CULTIVAR AND FERTILISER TREATMENT

\begin{tabular}{|c|c|c|c|c|c|c|}
\hline \multirow[t]{2}{*}{ Cultivars } & \multicolumn{2}{|c|}{2013} & \multicolumn{2}{|c|}{2014} & \multicolumn{2}{|c|}{2015} \\
\hline & Control & Fertilised & Control & Fertilised & Control & Fertilised \\
\hline White Transparent & 3 & $4^{\mathrm{a}}$ & $4^{\mathrm{a}}$ & $4^{\mathrm{a}}$ & 2 & $3^{\mathrm{a}}$ \\
\hline Kovalenkovskoye & 6 & $4^{\mathrm{a}}$ & $3^{\mathrm{a}}$ & $3^{\mathrm{a}}$ & 4 & $4^{\mathrm{a}}$ \\
\hline Antei & 3 & $4^{\mathrm{a}}$ & $2^{\mathrm{a}}$ & $4^{\mathrm{a}}$ & 2 & $3^{\mathrm{a}}$ \\
\hline Rubin & 4 & $6^{\mathrm{a}}$ & $6^{\mathrm{b}}$ & $8^{\mathrm{b}}$ & 2 & $10^{\mathrm{c}}$ \\
\hline Gita & 4 & $8^{\mathrm{b}}$ & $6^{\mathrm{b}}$ & $7^{\mathrm{b}}$ & 4 & $9^{c}$ \\
\hline$\underline{\text { Ligol }}$ & 3 & $6^{\mathrm{b}}$ & $2^{\mathrm{a}}$ & $5^{\mathrm{b}}$ & 3 & $6^{\mathrm{b}}$ \\
\hline Average & 4 & 6 & 4 & 5 & $3^{\mathrm{A}}$ & $6^{\mathrm{B}}$ \\
\hline
\end{tabular}

a, b and $\mathrm{c}-$ marked statistically significant ( $p<0.05$, Tukey) different groups of cultivar data within treatments (columns).

A and B - marked statistically significant $(p<0.05$, Tukey) different groups of treatment data.

EFFECT OF FERTILISER TREATMENT ON GROWTH AND YIELD OF APPLE CULTIVARS

\begin{tabular}{|c|c|c|c|c|}
\hline \multirow[t]{2}{*}{ Cultivar } & \multicolumn{2}{|c|}{$\begin{array}{c}\text { Increase of TCSA, } \mathrm{cm}^{2} \\
(2013-2015)\end{array}$} & \multicolumn{2}{|c|}{$\begin{array}{l}\text { Cumulative yield, kg per tree, } \\
(2013-2015)\end{array}$} \\
\hline & Control & Fertilised & Control & Fertilised \\
\hline White Transparent & $4.6^{\mathrm{a}}$ & $6.4^{\mathrm{a}}$ & $17.2^{\mathrm{a}}$ & $15.1^{\mathrm{a}}$ \\
\hline Konfetnoye & $5.0^{\mathrm{a}}$ & $5.2^{\mathrm{a}}$ & $21.2^{\mathrm{b}}$ & $21.8^{\mathrm{b}}$ \\
\hline Kovalenkovskoye & $8.0^{\mathrm{b}}$ & $7.5^{\mathrm{b}}$ & $30.9^{\mathrm{c}}$ & $39.3^{\mathrm{c}}$ \\
\hline Antei & $6.0^{\mathrm{a}}$ & $7.8^{\mathrm{ab}}$ & $24.6^{\mathrm{b}}$ & $24.5^{\mathrm{b}}$ \\
\hline Rubin & $6.9^{\mathrm{a}}$ & $7.9^{\mathrm{ab}}$ & $23.2^{\mathrm{b}}$ & $21.5^{\mathrm{b}}$ \\
\hline Gita & $8.8^{\mathrm{b}}$ & $12.9^{\mathrm{c}}$ & $48.5^{\mathrm{d}}$ & $38.9^{c}$ \\
\hline Ligol & $10.4^{\mathrm{c}}$ & $12.1^{\mathrm{c}}$ & $40.0^{\mathrm{c}}$ & $43.6^{\mathrm{d}}$ \\
\hline Average & $7.1^{\mathrm{A}}$ & $8.5^{\mathrm{B}}$ & 29.4 & 29.3 \\
\hline
\end{tabular}

a, b, c and d - marked statistically significant ( $p<0.05$, Tukey) different groups of cultivar data within treatments (columns).

A and B - marked statistically significant ( $p<0.05$, Tukey) different groups of treatment data. 
Cultivars 'Rubin' and 'Ligol' had a longer vegetative season because the leaves (foliage) of these cultivars were conserved on the tree and was less coloured than others during observations made in autumn 2015 (Table 4). This was particularly evident for 'Ligol' when nitrogen fertilisers were applied.

Significant differences in fruit mass were observed between cultivars (Table 5). The early cultivar 'Konfetnoye' had the smallest fruits. 'Ligol', 'Antei', 'Gita', and 'Rubin' had larger fruits that were medium and late ripening. Fruits were larger in the treatment with nitrogen fertiliser, but the difference was not significant compared to the control.

Leaf and fruit mineral concentrations did not significantly differ between control and $6 \mathrm{~g} \cdot \mathrm{m}^{-2}$ nitrogen fertiliser treatments (Table 6). 'Konfetnoye' had the highest concentration of nitrogen, which significantly differed from that of

EFFECT OF FERTILISER TREATMENT ON BIENNIAL YIELDING AND FOLIAGE COLOURING OF APPLE CULTIVARS

\begin{tabular}{|c|c|c|c|c|}
\hline \multirow[t]{2}{*}{ Cultivar } & \multicolumn{2}{|c|}{$\begin{array}{l}\text { Index of biennial yielding } \\
2014 / 2015\end{array}$} & \multicolumn{2}{|c|}{$\begin{array}{l}\text { Colouring of foliage } \\
(0-9 \text { point })\end{array}$} \\
\hline & Control & Fertilised & Control & Fertilised \\
\hline White Transparent & $0.5^{\mathrm{a}}$ & $0.6^{\mathrm{ab}}$ & $7^{\mathrm{c}}$ & $7^{\mathrm{c}}$ \\
\hline Konfetnoye & $0.4^{\mathrm{a}}$ & $0.4^{\mathrm{a}}$ & $6^{\mathrm{c}}$ & $6^{\mathrm{c}}$ \\
\hline Kovalenkovskoye & $0.4^{\mathrm{a}}$ & $0.3^{\mathrm{a}}$ & $6^{\mathrm{c}}$ & $6^{\mathrm{c}}$ \\
\hline Antei & $0.9^{\mathrm{b}}$ & $0.9^{\mathrm{b}}$ & $8^{c}$ & $7^{\mathrm{c}}$ \\
\hline Rubin & $0.8^{\mathrm{b}}$ & $1.0^{\mathrm{c}}$ & $5^{\mathrm{b}}$ & $6^{\mathrm{c}}$ \\
\hline Gita & $0.3^{\mathrm{a}}$ & $0.5^{\mathrm{a}}$ & $8^{c}$ & $8^{\mathrm{c}}$ \\
\hline$\underline{\text { Ligol }}$ & $0.8^{\mathrm{b}}$ & $0.8^{\mathrm{b}}$ & $5^{\mathrm{b}}$ & $3^{\mathrm{a}}$ \\
\hline Average & 0.6 & 0.6 & 7 & 6 \\
\hline
\end{tabular}

$\overline{\mathrm{a}, \mathrm{b}, \mathrm{c}-\text { marked }}$ statistically significant ( $p<0.05$, Tukey) different groups of cultivar data within treatments (columns).

EFFECT OF FERTILISER TREATMENT AND CULTIVAR ON FRUIT MASS

\begin{tabular}{|c|c|c|c|c|c|c|}
\hline \multirow[t]{2}{*}{ Cultivars } & \multicolumn{2}{|c|}{2013} & \multicolumn{2}{|c|}{2014} & \multicolumn{2}{|c|}{2015} \\
\hline & Control & Fertilised & Control & Fertilised & Control & Fertilised \\
\hline White Transparent & $176^{\mathrm{a}}$ & $202^{\mathrm{a}}$ & $120^{\mathrm{b}}$ & $125^{\mathrm{b}}$ & $123^{\mathrm{a}}$ & $155^{\mathrm{a}}$ \\
\hline Kovalenkovskoye & $213^{\mathrm{b}}$ & $240^{\mathrm{b}}$ & $124^{\mathrm{b}}$ & $143^{\mathrm{b}}$ & $136^{\mathrm{a}}$ & $140^{\mathrm{a}}$ \\
\hline Antei & $254^{\mathrm{b}}$ & $279^{\mathrm{b}}$ & $179^{\mathrm{c}}$ & $182^{c}$ & $228^{\mathrm{b}}$ & $242^{\mathrm{b}}$ \\
\hline Rubin & $267^{\mathrm{c}}$ & $340^{\mathrm{c}}$ & $188^{\mathrm{c}}$ & $206^{\mathrm{c}}$ & $163^{b}$ & $198^{\mathrm{b}}$ \\
\hline Gita & $234^{\mathrm{b}}$ & $291^{\mathrm{b}}$ & $154^{\mathrm{c}}$ & $183^{c}$ & $209^{b}$ & $216^{\mathrm{b}}$ \\
\hline Ligol & $265^{\mathrm{c}}$ & $297^{\mathrm{c}}$ & $189^{\mathrm{c}}$ & $198^{\mathrm{c}}$ & $193^{\mathrm{b}}$ & $220^{\mathrm{b}}$ \\
\hline Average & 223 & 261 & 148 & 160 & 167 & 185 \\
\hline
\end{tabular}

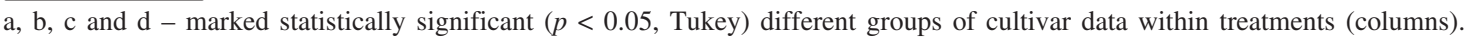

Table 6

NITROGEN CONTENT OF APPLE LEAVES AND FRUITS OF CULTIVARS WITH POSSIBLE FRUIT PHYSIOLOGICAL DISORDERS IN 2015

\begin{tabular}{|c|c|c|c|c|}
\hline \multirow[t]{2}{*}{ Cultivars } & \multicolumn{2}{|c|}{ Nitrogen in leaves, $\%$} & \multicolumn{2}{|c|}{ Nitrogen in fresh fruit mass, $\mathrm{mg} \cdot 100 \mathrm{~g}^{-1}$} \\
\hline & Control & Fertilised & Control & Fertilised \\
\hline White Transparent & $1.4^{\mathrm{a}}$ & $1.8^{\mathrm{a}}$ & $54^{\mathrm{b}}$ & $61 b$ \\
\hline Konfetnoye & $2.7^{\mathrm{b}}$ & $2.6^{\mathrm{b}}$ & $64^{\mathrm{b}}$ & $66 b$ \\
\hline Kovalenkovskoye & n.a. & n.a. & n.a. & n.a. \\
\hline Antei & $1.7^{\mathrm{a}}$ & $2.0^{\mathrm{a}}$ & $57^{\mathrm{b}}$ & $55^{\mathrm{b}}$ \\
\hline Rubin & $2.4^{\mathrm{a}}$ & $2.5^{\mathrm{a}}$ & $48^{\mathrm{a}}$ & $43^{\mathrm{a}}$ \\
\hline Gita & $2.4^{\mathrm{a}}$ & $2.1^{\mathrm{a}}$ & $51^{\mathrm{a}}$ & $39^{\mathrm{a}}$ \\
\hline$\underline{\text { Ligol }}$ & n.a. & n.a. & n.a. & n.a. \\
\hline Average & 2.1 & 2.2 & 55 & 53 \\
\hline
\end{tabular}

$\mathrm{a}, \mathrm{b}, \mathrm{c}$ and $\mathrm{d}-$ marked statistically significant $(p<0.05$, Tukey) different groups of cultivar data within treatments (columns).

n.a. - not analysed. The nitrogen content determined of cultivars with observed and possible physiological disorders of fruits only. 
other cultivars. 'White Transparent' and 'Antei' had the lowest concentration of nitrogen in leaves. 'Rubin' and 'Gita' had the lowest concentration of nitrogen in fruits and the highest in 'Konfetnoye'.

\section{DISCUSSION}

The trial was performed with two fertilisation treatments control and $6 \mathrm{~g} \cdot \mathrm{m}^{-2}$ nitrogen. Excessive growth at these levels can be observed in some orchards. The general idea was to provide balanced growth and production to obtain regular yields. In certain conditions, with proper management of tree canopy and reduced competition with weeds in tree rows, we observed sufficient tree growth. The development of long shoots must be reduced together with managing the nitrogen available to the trees particularly for cultivars that develop flower buds at the end of short shoots. The strong and long shoots tend to cause excessive vegetative growth. Difference in the ration of long and short shoots (1:5-7) was much higher in the control treatment than in the treatment with nitrogen fertiliser (1:3-4). Yield and growth data showed that some cultivars had better performance in production when shorter shoots developed, i.e. in the control. This can partly be explained by a relatively high concentration of organic matter in the soil $-21 \mathrm{~g} \cdot \mathrm{kg}^{-1}$ (by Tyurin method) or $2.1 \%$, which is sufficient for growth of apple trees. Soil organic matter concentration was closely correlated with nitrogen concentration. Soil nitrogen transforms to a plant available form by mineralization of organic matter (Ernani et al., 2008). E. Fallahi (Fallahi et al., 2010) suggested to provide the apple trees with up to $250 \mathrm{~kg} \cdot \mathrm{ha}^{-1}$ nitrogen, but in that study the soil organic matter concentration was only $0.5 \%$. Other investigations (Teravest et al., 2010) have shown that larger dosages of nitrogen can be suitable in nutrient poor soils with very low organic matter concentration. However, larger dosage of nitrogen in poor soils can increase nitrogen losses by leaching etc. (Neilsen et al., 2014). Although the cumulative yield in fifth to seventh year after planting (2013-2015) did not different between the fertilisation treatments, we observed some trial factor interactions. Positive effect of nitrogen was observed only for cultivars 'Konfetnoye', 'Kovalenkovskoye', and 'Ligol' (Table 3). 'Gita' had significantly larger cumulative yield in control. Also in Poland no effect of nitrogen fertilisation was found on apple-tree growth and productivity, due to good soil preparation before orchard establishment, maintaining herbicide strips along tree rows and therefore increasing available nitrogen concentration in the soil during the vegetative period (Wrona, 2011).

Cultivar 'Rubin' (Kazakhstan) had excessive growth (amount of long shoots) even in the control treatment, but it is essential that this cultivar must have more short shoots $(40 \mathrm{~cm})$ to maintain good production and not to develop blind wood, which was shown by the obtained yield data (Table 3). There was significant increase of biennial bearing of cultivar 'Rubin' in the nitrogen treatment. In 2015, nitrogen fertilisation promoted excessive growth of 'Rubin' by development of long shoots, because of biennial bearing.
During this study the largest yield was obtained in 2014. Early ripening cultivars had less pronounced biennial bearing.

The trunk cross-sectional area (TCSA) usually should have a positive correlation with yield. In this trial some negative relationships between cumulative yield and TSAP were observed for cultivars 'White Transparent', 'Antei', 'Rubin', and especially cultivar 'Gita' (Table 3 ) in the period 2013-2015. However, it should be pointed out that so far we have analysed a short period of the trial, and to generation of conclusions could be hasty in this case.

In conditions of Latvia it is important to promote winterhardiness of trees. However, 'Ligol' has a relatively long vegetation period, which is shown by foliage colouring, late harvest time, and it has the worst winter-hardiness of all cultivars in the trial and commercially used in orchards. This characteristic was worsened by application of nitrogen as shown by data on foliage colouring (Table 4). The risk of reduced winter-hardiness increases with use of nitrogen fertiliser, as trees can complete growth and be ready for dormancy at a time when the lightly coloured leaves are still photosynthetically active and growing.

Nitrogen fertilisation resulted in increased fruit mass, but the difference was not statistically significant at $p<0.05$ (Table 5). The fruits were larger in off years of yielding. It is known that too large fruits suffer from physiological disorders, especially during storage. Large fruits must be harvested and consumed first. However, the cultivar 'Konfetnoye' had the highest nitrogen concentration in leaves and one of the highest in fruits, but had the smallest fruits, which was not expected (Table 5 and 6). In 'Rubin' and 'Gita', there was no relationship with cultivar ripening time. A suggestion could be to use nitrogen fertilisers, probably, with double dosage, for cultivars with small fruits. However, there is no direct relationship between nitrogen fertiliser application and yield (Wrona, 2011). It is well known and shown by our data that nitrogen increases growth. Excessive growth causes increase of needs of pruning and expenses of canopy training for growth reduction. In our climate this also may have negative effect on tree winter-hardiness. Probably, nitrogen fertilisers are needed to maintain growth and yields only in conditions of low organic matter in soil (Fallahi et al, 2010; Teravest et al., 2010).

Nitrogen treatment increased the proportion of unacceptable shoot types of all cultivars included in trial. Nitrogen significantly increased the amount of unacceptable shoots of cultivars 'Gita', 'Rubin', and 'Ligol'. Additional nitrogen as fertiliser had no significant effect on the growth and yield of cultivars 'Antei', 'White Transparent', and 'Konfetnoye'. The cumulative yield of 'Kovalenkovskoye' and 'Ligol' was positively affected by nitrogen fertiliser. Cultivar ' $\mathrm{Ru}$ bin' had the most pronounced biennial bearing. Cultivar 'Ligol' had the most active and longest vegetation, particularly in the nitrogen treatment. 


\section{ACKNOWLEDGEMENTS}

The study was supported by the project "Investigation of apple, plum and cherry cultivars and rootstocks suitability and development of technologies for sustainable farming in different regions of Latvia" financed by the Latvian Ministry of Agriculture.

\section{REFERENCES}

Chen, B. C., Lai, H. Y., Liu, C. W., Sung, Y. (2014). Effects of nitrogen fertilisers on the growth and nitrate content of lettuce (Lactuca sativa L.). Int. J. Environ Res. Public Health, 11 (4), 4427-4440.

Cmelik, Z., Tojnko, S., Unuk, T. (2006). Fruit quality of 'Fuji' apple as affected by crop load and rates of nitrogen. Acta Hortic., 721, 147-152.

Ernani, P. R., Rogeri, D. A., Proenca, M. M., Dias, J. (2008). Addition of nitrogen had no effect on yield and quality of apples in a high density orchard carrying a dwarf rootstock. Rev. Bras. Frutic., 30 (4), 1113-1118.

Fallahi, E., Fallahi, B., Neilsen, G. H., Neilsen, D., Peryea, F. J. (2010). Effects of mineral nutrition on fruit quality and nutritional disorders in apples. Acta Hortic., 868, 49-60.

Gastal, F., Lemaire, G. N. (2002). Uptake and distribution in crops: An agronomical and ecophysiological perspective. J. Exp. Bot., 370 (53), 789-799

Neilsen, G. H., Forge, T. A., Angers, D. A., Neilsen, D., Hogue, E. J. (2014). Suitable orchard floor management strategies in organic apple orchards that augment soil organic matter and maintain tree performance. Plant Soil, 378 (1-2), 325-335.

Neilsen, G. H., Neilsen, D., Guak, S., Forge, T. A. (2015). The effect of deficit irrigation and crop load on leaf and fruit nutrition of fertigated Ambrosia/M.9 apple. HortScience, 50 (9), 1387-1393.
Sharifi, M., Zebarth, B. J., Burton, D. L., Rodd, V., Grant, C. A. (2011). Long-term effects of semisolid beef manure application to forage grass on soil mineralizable nitrogen. Soil Sci. Soc. Amer. J., 75 (1), 649-658.

Skrivele M., Dimza I., Rubauskis E. (2000). The cropping of nine apple cultivars as influenced by two different rootstocks. Fruit Sci. (Tartu), Nr. 207, 100-103

Surikova, V., Kārkliņ̌̌, A., Rubauskis, E., Skrīvele, M., Berlands, V. (2008). Influence of soil management treatment on root systems of apple-trees. In: Sustainable Fruit Growing: from Plant to Product: Proceedings of International Scientific Conference, 28-31 May 2008, Jūrmala. Latvia State Institute of Fruit Growing, Dobele, pp. 227-232.

Tagliavini, M., Scudellazi, D., Marangoni, B., Toselli, M. (1996). Nitrogen fertilisation management in orchards to reconcile productivity and environmental aspects. Fertiliser Res., 43 (1), 93-102.

Tamme, T., Reinik, M., Roasto, M. (2009). Nitrates and nitrites in vegetables: Occurrence and health risks. In: Watson, R. R., Preedy, V. R. (eds.). Bioactive Foods Promoting Health: Fruits and Vegetables. Academic Press, Salt Lake City, pp. 307-321.

Teravest, D., Smith. J. L., Boggs, L. C., Hoagland, L., Granatstein, D., Reganold, J. P. (2010). Influence of orchard floor management and compost application timing on nitrogen partitioning in apple trees. HortSci., 45 (4), 637-642.

Wang, Z. H., Zong, Z. Q., Li, S. X., Chen, B. M. (2002). Nitrate accumulation in vegetables and its residual in vegetable fields. Environ. Sci., 23 (3), 79-83.

Weinbaum, S. A., Johnson, R. S., Dejong, T. M. (1992). Causes and consequences of over fertilisation in orchards. HortTechnol., 2 (1), 112-121.

Wrona, D. (2011). The influence of nitrogen fertilisation on growth, yield and fruit size of 'Jonagored' apple trees. Acta Sci. Pol., Hortorum Cultus, 10 (2), 3-10.

\section{ĀBEL̨U AUGŠANA UN RAŽOŠANA SLĀPEKL̦A MĒSLOJUMA IETEKMĒ LATVIJAS APSTĀKḶOS}

Slāpeklis ir galvenais barības elements, kas nepieciešams vairākām augu dzīvības funkcijām — veǵetatīvajai augšanai, ziedpumpuru un aug̣̣u veidošanai. Latvijā slāpekḷa mēslojuma izmantošanu limitē uz ES Nitrātu direktīvas pamata izveidotie Latvijas Ministru kabineta noteikumi, kas izstrādāti, pamatojoties uz vidi saudzējošās augḷu un ogu ražošanas pamatnostādnēm. Pētījuma mērḳis bija slāpekḷa mēslojuma ietekmes izpēte uz ābeḷu veǵetatīvo augšanu un ražas parametriem. Pētījums veikts 2013.-2015. gadā septin̄ām škirnēm, potcelms B.396. Salīizināti divi mēslojuma varianti — kontrole (bez slāpekḷa) vai slāpekḷa mēslojums $6 \mathrm{~g} \cdot \mathrm{m}^{-2}$. Slāpekḷa mēslojums negatīvi ietekmēja vēlamo (līdz $40 \mathrm{~cm}$ ) un nevēlamo (virs $40 \mathrm{~cm}$ ) dzinumu attiecību visām pētījumā iekḷautajām škirnēm, un škirnēm 'Gita', 'Rubin' (Kazahijas) un 'Ligol' būtiski palielināja nevēlamo (virs $40 \mathrm{~cm}$ ) dzinumu skaitu. Škirnes 'Antei', 'Baltais Dzidrais' un 'Konfetnoje' šajā pētījumā raksturotas kā stabilākās, kurām slāpekḷa mēslojuma ietekmē būtiski nemainījās ne veǵetatīvā augšana, ne arī ražas parametri. Šḳirnēm vērojama atškiirīga slāpekḷa ietekme uz kopražu trīs gadu periodā. Slāpekḷa mēslojums būtiski palielināja kopražu škiirnēm 'Koval̦enkovskoje' un 'Ligol', bet šķirnei 'Gita' lielāka raža konstatēta kontroles variantā. Škirnēm 'Gita' un 'Rubin' slāpekḷa ietekmē būtiski vairāk izpaudās ražošanas periodiskums. Lapu zaḷā krāsa ilgāk saglabājās škirnei 'Ligol', tas norāda uz fotosintēzes aktivitāti, bet līdz ar to pastāv ziemcietības samazināšanās risks. 